Kelvin for his address, mentioned that for thirty years he himself sat at the feet of Joule, whom he might therefore claim in some sense as his scientific father. He remained in constant com. munication with Joule up to the day of the philosopher's death. It was a great thing that in a city like Manchester, devoted as it was to industry and commerce, the citizens should be entitled to place in their Town Hall the statues of two such fellowcitizens as Dalton and Joule. Few cities in the world could boast of two greater men. In London, also, they had been doing something to show the appreciation in which not only this country but the world held Joule. A sum of money had been raised and placed in the hands of the Royal Society for the purpose of founding a Joule studentship, and on Thursday the Council of the Society resolved that the money should be spent in founding such a scholarship, to be awarded alternately in England and in other countries, for the purpose of encouraging young scientific men to walk in the steps of Manchester's great citizen. The first of those scholarships, of the value of $£$ roo, would be shortly awarded, and he thought he was not going too far when he said it would come to the city in which Joule lived and worked. He might mention that since the foundation of Owens College that institution could claim nine medallists of the Royal Society, and had they lived Prof. Jevons and Prof. Schorlemmer would have been added to the number. It would be seen, therefore, that Manchester had taken up the thread spun by Dalton and Joule, and that there was no reason to fear that their work would not be continued.

Prof. Osborne Reynolds seconded the resolution, which was adopted.

On the motion of Mr. Alderman Malk, seconded by Principal Ward, a vote of thanks was given to the Lord Mayor for presiding. At the conclusion of the proceedings the Lord Mayor and Lady Mayoress held a reception in the state apartments.

\section{THE ETHNOLOGICAL MUSEUM AT}

\section{LE YDEN.}

I T is from twenty-five to thirty years ago that the interest in ethnology as a science was awakened. Ethnological objects are no longer considered by scientific men as mere curiosities; collections of them have ceased to be shops of foreign bric-a-brac. In America and in Europe, museums have arisen, variable in size and importance it is true, but all with the same object in view, viz. the study of man from his handiwork as illustrative of his mental development in various directions, in time as well as in space.

The realisation of the importance of collecting and studying ethnological material in distant lands has not come too soon. What has been done in this respect within the last twenty-five years surpasses all that has been performed in the centuries before, from the beginning of the circumnavigation of the globe to the early seventies of our century. The result of this has not only been the publication of valuable ethnological monographs and studies, but also the foundation of new, and the further development of existing, museums in Europe and America. Amongst the ethnological collections which have grown considerably are those of the National Ethnological Museum at Leyden. A pamphlet by the director, Dr. L. Serrurier, recently published under the very suggestive title of "Museum or Storehouse?" induces me to write the present notice.

The origin of this museum dates back as far as 1837 , the year in which the Dutch Government purchased von Siebold's Japanese collections. This formed the nucleus of the little museum, which gradually increased by means of collections made in the Indian Archipelago by Macklot, Salomon Müller, von Rosenberg, and other naturalists. In the meanwhile von Siebold had returned to Japan, and the late Dr. Leemans was appointed acting director of the collection in 1859 , as a part of the National Museum of Antiquities. A long period of inactivity then ensued until 1880 , when it was decided that the ethnological department should become a separate museum, under the direction of Dr. Serrurier, until then curator of the Japanese department.

From that moment the museum sprang into new life. The period of curiosity shop had ceased for ever; and the institution was developed in the right direction. Many objects were properly identified, check lists and manuscript catalogues corrected and newly made, ${ }^{1}$ relations with sister institutions established, exchanges made, and valuable objects and collections bought. Many residents in the Dutch colonies who hitherto had hardly heard of the existence of an ethnological museum at Leyden, now gladly presented or loaned their private collections to it. Nothing shows more clearly the extraordinary growth of these collections than the maps accompanying the pamphlet of Dr. Serrurier. On these maps-two of the world, and two of the Indian Archipelago-is indicated the number of groups of objects in the Leyden Museums representing special ethnological regions or areas. These groups refer to a very rational division or classification established by Dr. Serrurier and used in the Leyden Museum. One set of maps shows the condition of the collections in $188 \mathrm{r}$, the other in 1893 . A single glance at the maps is sufficient to illustrate the vast dif ference wrought in those twelve years. Southern Asia, the Orient, Africa, and North America were hardly or not at all represented in 188I, and so were many parts of the Indian Archipelago and South America, but in 1893 the ethnology of these countries can be studied in the museum by means a valuable and more or less representative collections. In short the collection has decupled in these twelve years, not to speak of the rich and varied anthropological section, entirely the work of the present director.

It would be only natural to suppose that collections of this importance were exhibited in a special building where they were not only safely stored but also made of interest to the public, as well as for professional men, Nothing is, however, farther from the reality than this supposition. To the amazement of foreign ethnologi.ts, and every friend of science in fact, the Leyden collections are scattered, as Dr. Serrurier summarises, over not less than five different places-ugly, dark, and damp private houses, or other localities, all equally unfit for the conservation of the ethnological material. Thousands of precious objects are stowed away as in a storehouse, where moths and moisture are hard to fight against, and where the danger of fire is so much greater than elsewhere. Should ever a fire destroy these collections, the loss would, for the greater part of them, be irrepatable; they could not be again collected. In many distant countries, all over the world, the inhabitants have given up their native industries, and are losing rapidly their originality in every respect, the result of their contact with Western civilisation.

An appendix to Dr. Serrurier's pamphlet, being a number ( $f$ testimonies from different travellers and authors as to the disappearance of primitive conditions among foreign races, tends to prove the value of present ethnological collections and the necessity of collecting objects and data without delay, befure it will be too late.

Irrespective, however, of the present buildings the museum collections are not quite what they ought to be, which perhaps is partly due to the fact that they are situated in a small old fashioned city with a public-University students includedtaking very little or no interest in ethnological exhibitions. If the museum were situated in a great city, say Amsterdam or The Hague, things might probably take a turn for the better, but still, as long as there is no special building, a thorough improvement will be impossible.

There are many things which the Fthnological Museum of Leyden ought to be, and should be, if proper attention was paid to it by the Dutch government. For a nation like the Dutch, which ranks third as a colonial power, a museum like this could be a sort of a bureau of ethnology, more or les; similar to that of Washington, and a place where both University students and the general public could be taught sounder ideas about races of mankind which they have been used to consider as "savages."

For years past the director has called the attention of the Dutch government to this state of things. In each of his annual reports Dr. Serrurier has pleaded for the sake of a new and proper building with the arduur and conviction of a man who pleads for the thing to which he devotes his life and talents, but all in vain ; vox clamantis in deserto.

The present pamphlet of Dr. Serrurier's is a supreme effort to improve this sad state of affairs, a last appeal to the national

1 A system of cataloguing introduced not long ago by Dr. Serrurier in the Leyden Museum, as far as I know not followed in any other ethnological museum, is what might be called the "Note Catalogue." Each object has an inventory number referring to a separate note on a slip of stiff paper. has an inventory number referring to a separate note on a slip of stiff paper which contains, besides a small photopraph of the object in question, a full currence, use, \&c. This system facilitates greatly the s:tidy of the ubjects. 
representatives, the members of the First and Second Chambers. The granting of a considerable sum of money for the building of a new National Museum of Natural History at Leyden, a necessity long felt and perseveringly advised by its director -Dr. Jentink-furnished an occasion to bring the question once more before the public. What the result will be-museum or storehcuse?-we cannot tell. If a man is not convinced after reading Dr. Serrurier's pamphlet, he will never become convinced.

"But whatever may be done"-Dr. Serrurier concludes his interesting paper-" "every change, in this case, will be an improvement, for now the life of the museum is ebbing away. The time is near that it will sink into a lethargic sleep, the end of which will be death."

H. TEN KATE,

\section{UNIVERSITY AND EDUCATIONAL}

\section{INTELLIGENCE.}

OXFORD.-Mr. T. I. Pocock, of Corpus, has recently been elected to the Burdett-Coutts Geological Scholarship. It is his intention, we believe, to devote himself uitimately to the science of astronomy, which he studied at Oxford under the late Prof. Pritchard.

Mr. E. A. Minchin has been elected to a Biological Fellowship" at Merton College, and Mr. H. M. Vernon, of that college, has teen elected to the Oxford Biological Scholarship at Naples.

CAMIBRIDGE. - The council of the Royal Gengraphical Society offer in the present academical year a studentship of $f$ roo, to be used in the geographical investigation (physical or historical) of some district approved by the council. Candidates must be members of the University of not more than eight years standing fro:n matriculation, who shall have attended the courses given in Cambridge by the late or present University lecturer in geography.

The following awards in Natural Science were made at St. John's College on December i I :-K. C. Browning (Dulwich College), Foundation Scholarship of $£ 80$; E. R. Clarke (Tonbridge School), Foundation Scholarship of $£ 50$; O. F. Diver (Winchester College) and K. B. Williamson (St. Paul's School), Minor Scholarships of $£ 50 ; A . A$. Robb (Queen's College, Belfor1), R. F. C. Ward (Epsom College), J. A. Glover (St. Paul's Schcol), and G. D. M'Cormick (Exeter Grammar School), to various Exhibitions of $\Varangle 50$ and under.

\section{SOCIETIES AND ACADEMIES.}

\section{LONDON.}

Linnean Society, November 16.--Prof. Stewart, President, in the chair.-Mr. J. H. Veitch exhibited a large and interesting collection of economic and other vegetable products of Japan, recently brought by him from that country, and described the various uses to which different kinds of wood, fibre, grase, \&c., were applied for domestic purposes, as also the way in which various seaweeds were collected and prepared for food. -Mr. A. G. Renshaw exhibited a remarkably large specimen of the giant puffball, Lycoperdon giganteum, which he had gathered at Catford Bridge.-On behalf of the Rev. Prebendary Gordon, the secretary exhibited a plant of Veronica salicifolia of New Zealand, found growing in Langland's Bay, Mumbles, Swansea, having been introduced by some chance,-A paper was then read by the Rev. G. Henslow, on the origin of plant structures by self-adaptation to the environment, exemplified by desert and xerophilous plants. The purport of this paper was to prove by a direct appeal to facts the probably universal application of Mr. Darwin's assertions, viz.: (I) that natural selection has no relation whatever to the primary cause of any modification of structure ("Animals and Plants, \&c." vol. ii. p. 272); (2) that modifications of structure are due to the direct action of the environment (fide Darwin, Weismann, Spencer, \&c.). This always results in "definite variations," by which Mr. Darwin signifies (3) that all, or nearly all, the individuals became modified in the same way ("Origin of Species," 6th ed., p. 106), and con. sequently (4) that " a new variety would be produced without the aid of natural selection " ("Animals and Plants," ii. 27I, "Origin of Species," pp. 72, I75). Mr. Henslow showed (1) that all the species constituting the peculiar facies of a desert flora are the direct result of their climatic conditions; (2) that these peculiarities are in nearly all cases of the utmost benefit to the plants, such as the hardening of the tissues, the reduction of parenchyma, the minute size of the leaves, the dense clothing of hair, a thick cuticle, the presence of wax, storage of water tissues, \&c. But (3) these features are just those which systematists utilise as descriptive characters of varieties and species. Mr. Henslow observed that by Darwin's assuming that "indefinite variations" which are characteristic of cullization were equally so in nature, he reasonably required natural selection to correspond with artificial selection; but that as sumption he believed to be erroneous. For experiments proved that by sowing seeds in a very different medium, all the seedlings vary in the same direction, viz. that of adaptation to the new environment, verifying Mr. Herbert Spencer's statement that " under new conditions the organism immediately begins to undergo certain changes in structure, fitting it for its new conditions." The conclusion is thus arrived at which is expressed in the title of this paper. The functions of natural selection therefore become limited, as follows: (I) The survival of the constitutionally strongest amongst seedlings; (2) delimitation of species by the non-reproduction of intermediate forms ; (3) the geographical distribution of plants by self-adaptation. An interesting discussion followed, in which Prof. Reynolds Green, the Rev. Dr. Klein, Mr. Perry Coste, and others took part.

Zoological Society, November 21.--Sir W. II. Flower, K.C.B., F.R.S., President, in the chair. - The secretary read a report on the additions that had been made to the Society's menagerie during the month of October, I893, and called special attention to an example of Goliath beetle (Goliathus drutrit), the largest of known Coleoptera, obtained near Accra, and presented October 5, by Mr. F. W. Marshal, and to an adult female and a young of the Manatee (Manatus americanus), captured in Manatee Bay, Jamaica, and most kindly sent home for the Society's collection by Sir Henry A. Blake. Unfortunately the Manatees had reached the gardens in a very exhausted condition, and died soon after their arival. - The secretary read an extract from a letter addiessed to bim by Mr. J. S. Mackay, of the Kangra District, Punjaub, relating to a young snow-leopard which he had in captivity, and exhibited some photographs of this animal.-Mr. Sclater exhibited and made remarks on a mounted specimen of an African monkey (Cercopithecus albogutaris) belonging to the Leyden Museum. - Mr. W. B. Tegetmeier exhibited and made remarks on two hybrid pheasants, believed to be crosses between the common pheasant and the gold and silver pheasants.-A communication was read from Messrs. G. W. and E. C. Peckham, on the spiders of the family Attida of the island of St. Vincent, based on specimens collected in that island by the agency of the joint committee of the Royal Society and the British Association for the exploration of the Lesser Antilles. The series had been collected by Mr. Herbert H. Smith and Mrs. Smith, who had been specially sent to the island as skilled collectors by Mr. F. D. Godman, F.R.S.-A communication was read from $\mathrm{Mr}$. P. R. Uhler, containing a list of the Hemiptera Heteroptera collected in the island of St. Vincent by Mr. and Mrs. Herbert H. Smith, with descriptions of new genera and species.-Dr. G. Lindsay Johnson made some observations on the refraction and vision of the eye of the common seal (Phoca vitulina).-Mr. Sclater read a paper on some specimens of mammals from Lake Mweru, British Central Africa, transmitted by Vice-Consul Alfred Sharpe, through Mr. H. H. Johnston, C.B. The specimens were referred to seventeen species, amongst which was a new monkey of the genus Cercopithecus, proposed to be called $C$. opisthostictus, and a new antelope allied to the waterbuck, which was named Cobus crazeshayi, after Mr. R. Crawshay, who had first discovered the species.

\section{CAMBRIDGE.}

Philosophical Society, November 27.-Prof. T. McK. Hughes, President, in the chair.-The following communications were made. - The action of light on bacteria, by Dr. H. Marshall Ward. By throwing the spectrum on various bacteria suspended in films of agar, it is possible to obtain photographic records of the action of the varions rays; because, after incubation, those spores or bacilli, \&c. which are killed by certain rays remain invisitle, whereas those still left capable of development render the agar opaque. The experiments show that those germs wh:ch are struck by the infra-red, red, orange and yellow, develop as rapidly as those $n t$ exposed to light at all. The action begins 